\title{
Hubungan Rasio Leukosit Mean Platelet Volume dengan Skor GRACE sebagai Prediktor Prognosis pada Pasien Sindrom Koroner Akut
}

Theresia llyan ${ }^{1}$, Herniah Asti Wulanjani², Edward Kurnia Setiawan Limijadi²

\begin{abstract}
Abstrak
Sindrom Koroner Akut (SKA) sebagian besar disebabkan aterosklerosis. Inflamasi kronis berperan dalam pembentukan plak aterosklerosis. Leukosit dan trombosit berperan pada proses inflamasi. Peningkatan leukosit dan Mean Platelet Volume (MPV) (penanda aktivasi trombosit) menjadi prediktor prognosis kurang baik pada SKA. Tujuan: Membuktikan hubungan rasio Leukosit MPV dengan skor GRACE sebagai prediktor prognosis pasien SKA. Metode: Penelitian potong lintang terhadap 51 pasien SKA onset 4-6 jam di RSUP Dr. Kariadi Semarang telah dilakukan selama bulan Maret sampai April 2019. Perhitungan rasio leukosit MPV dari hasil pemeriksaan hematologi pasien pertama kali saat rawat inap dan pengukuran skor GRACE dari rekam medis. Uji analisis dengan korelasi Pearson. Hasil: Uji korelasi Pearson untuk melihat hubungan antara rasio Leukosit MPV dengan skor GRACE, didapatkan $r=-0,088$ dan $p=0,538$ ( $p>0,05$ ). Analisis subgrup risiko kematian rendah, sedang, tinggi, didapatkan masing-masing $r=0,980 p=0,129 ; r=0,142 p=0,629 ; r=-0,112, p=0,527$. Terdapat korelasi lemah, dapat diabaikan dan tidak signifikan antara rasio leukosit MPV dan skor GRACE $(r=-0,088, p=538)$ pada pasien SKA dengan onset 4-6 jam. Hal ini mungkin disebabkan pengaruh faktor usia dan beberapa komponen dalam skor GRACE tidak berhubungan dengan inflamasi. Simpulan: Tidak terdapat hubungan antara rasio leukosit MPV dan skor GRACE.
\end{abstract}

Kata kunci: rasio leukosit mean platelet volume, sindrom koroner akut, skor GRACE

\begin{abstract}
Atherosclerosis remains the primary cause of Acute Coronary Syndrome (ACS). Chronic inflammation has a role in the formation of atherosclerotic plaque. Leucocyte and platelet play a role in the inflammatory process. An increase in leucocytes and Mean Platelet Volume (MPV) are poor prognostic predictor in ACS. Objectives: To determined the relationship between white blood cells MPV ratio and GRACE score as prognostic predictor in ACS patients. Methods: This was a cross sectional study on 51 ACS patients with 4-6 hours onset in RSUP Dr. Kariadi Semarang from Marc until April 2019. Leucocyte MPV ratio were calculated from hematology analyzer's on admission. Measurement of GRACE score taken from medical records. Analysis was done by Pearson's correlation test. Results: Pearson correlation test was conducted to assess the relationship between white blood cells MPV ratio and GRACE score with $r$ $=-0.088$ and $p=0.538$ ( $p>0.05$ ). In the analysis of low, moderate, and high risk mortality subgroups and GRACE score the results are respectively $r=0.980 p=0.129 ; r=0.142 p=0.629 ; r=-0,112, p=0,527$. There was a weak, negligible and not significant correlation between the white blood cells MPV ratio and GRACE score $(r=-0.088, p=$ 538) in ACS patients with 4-6 hours of onset. This may be due to the influence of age and some assessment components in GRACE scores are not related to inflammation. Conclusion: There is no relationship between leucocyte MPV ratio and GRACE scores.
\end{abstract}

Keywords: leucocyte mean platelet volume ratio, acute coronary syndrome, GRACE score

Affiliasi penulis: ${ }^{1}$ Program Pendidikan Dokter Spesialis Patologi Klinik, Fakultas Kedokteran Universitas Dlponegoro, Semarang, 2Bagian Patologi Klinik, Fakultas Kedokteran, Universitas Diponegoro, Semarang
Korespondensi: theresia.ilyan@gmail.com, liemsianhok@yahoo.com Telp: (024) 8311485 


\section{PENDAHULUAN}

Sindrom Koroner Akut (SKA) merupakan masalah kardiovaskular utama dengan angka kematian dan angka perawatan rumah sakit yang tinggi. Prevalensi penyakit jantung koroner di Indonesia menurut Riset Kesehatan Dasar Badan Penelitian dan Pengembangan Kesehatan tahun 2013 sebesar $0,5 \%$ di Jawa Tengah (120.447 orang). ${ }^{1}$ Sindroma Koroner Akut menyebabkan kematian 9$19 \%$ pada 6 bulan pertama setelah diagnosis, dengan setengah dari kematian terjadi dalam 30 hari pertama. ${ }^{2}$ Angka kejadian SKA semakin meningkat seiring dengan meningkatnya angka harapan hidup berkat kemajuan ilmu kedokteran. ${ }^{2,3}$

Sindrom Koroner Akut sebagian besar disebabkan aterosklerosis. Inflamasi kronis berperan dalam pembentukan plak aterosklerosis, selanjutnya dapat menyebabkan plak tidak stabil dan terbentuknya trombus. ${ }^{2,3}$ Leukosit berperan dalam proses inflamasi sehingga turut berperan pada kejadian SKA. ${ }^{4,5}$ Peningkatan jumlah leukosit pada SKA berhubungan dengan peningkatan penanda radang seperti $C$ reactive protein dan meningkatkan risiko SKA berulang maupun peningkatan angka mortalitas., Sel- T dan makrofag terdapat pada plak aterosklerosis yang akan teraktivasi setelah cedera endotel, kemudian memacu pembentukan trombus atas stimulasi sitokin dan prokoagulan. Proses ini meningkatkan trombogenisitas dan memicu perkembangan SKA. Trombosit telah dilaporkan berperan dalam SKA melalui jalur inflamasi. Trombosit teraktivasi dan tidak teraktivasi berperan dalam adhesi trombosit-leukosit, ikut mendukung aterogenesis. Saat terjadi ruptur plak, terjadi aktivasi trombosit dan pembentukan trombus. ${ }^{8}$ Interaksi trombosit dan leukosit menyebabkan rekrutmen leukosit meningkat di lokasi ruptur plak dan diperkirakan berperan penting pada kejadian dan prognosis SKA. Mean Platelet Volume (MPV) adalah penanda aktivasi trombosit dan penanda inflamasi yang telah diteliti menjadi penanda prognostik pada SKA, serta berhubungan dengan morbiditas dan mortalitas kardiovaskular. ${ }^{8,9}$

Komponen dari hitung darah lengkap, sebagai parameter yang murah dan mudah dilakukan, akhirakhir ini banyak diteliti dan ditemukan berhubungan dengan keluaran klinis atau prognosis pada Sindrom Koroner Akut. ${ }^{8}$ Rasio Leukosit MPV merupakan salah satu parameter hitung darah lengkap yang dapat digunakan dalam SKA yang belum banyak diteliti. Beberapa penelitian yang ada menunjukkan peningkatan rasio leukosit MPV secara independen dapat memprediksi insiden Kejadian Kardiovaskular Mayor jangka panjang dan risiko mortalitas pada pasien SKA. ${ }^{8,10,11}$

Sistem skoring risiko Global Registry of Acute Coronary Events (GRACE) dipakai untuk stratifikasi risiko kematian pada pasien SKA sehingga membantu menentukan strategi terapi yang tepat berdasarkan risiko individual. ${ }^{12-14}$ Skor GRACE rutin dinilai pada pasien di IGD RSUP Dr. Kariadi Semarang dengan diagnosis Sindrom Koroner Akut (Unstable Angina Pectoris-UAP, Non ST Elevation Myocardial InfarctionNSTEMI, dan ST Elevation Myocardial InfarctionSTEMI).

Rasio Leukosit MPV merupakan salah satu parameter hitung darah lengkap yang dapat digunakan dalam SKA yang belum banyak diteliti. Beberapa penelitian menunjukkan peningkatan rasio leukosit MPV secara independen dapat memprediksi insiden Kejadian Kardiovaskular Mayor jangka panjang pada pasien SKA. ${ }^{8}$

Skor GRACE rutin digunakan pada pasienpasien SKA yang baru masuk rumah sakit dengan diagnosis SKA namun penilaian ini memerlukan beberapa komponen yang tidak didapatkan dalam waktu cepat dan tidak tersedia di semua fasilitas kesehatan seperti kreatinin serum dan penanda kerusakan jantung, sementara pemeriksaan hematologi mudah dan cepat mendapatkan hasil jumlah leukosit dan MPV.

Penelitian ini dilakukan untuk membuktikan apakah rasio leukosit MPV yang merupakan gabungan gambaran kondisi inflamasi dapat menggambarkan/ berhubungan dengan skor GRACE dalam memprediksi prognosis pasien Sindrom Koroner Akut.

\section{METODE}

Penelitan ini merupakan cross sectional study yang dilakukan di Rumah Sakit Umum Pusat (RSUP) Dr. Kariadi Semarang selam Maret sampai April 2019. 
Pengambilan sampel dilakukan secara consecutive sampling dengan populasi target pasien sindrom koroner akut telah didiagnosis Dokter Spesialis Jantung dan Pembuluh Darah. Sebanyak 51 pasien memenuhi kriteria inklusi. Ethical clearance no. 188/EC/KEPK-RSDK/2019 diperoleh dari komite etik penelitian kesehatan RSUP Dr. Kariadi Semarang.

Sampel penelitian adalah sebagian atau mewakili populasi diteliti dengan memenuhi kriteria inklusi dan eksklusi. Kriteria inklusi pasien dengan diagnosis sindrom koroner akut (UAP, STEMI, NSTEMI) di Instalasi Gawat Darurat RSUP Dr. Kariadi Semarang, antara lain onset 4-6 jam, dengan suhu tubuh normal (suhu $\pm 36,5^{\circ} \mathrm{C}$ ), dan bersedia ikut dalam penelitan ini dengan menandatangani informed consent. Kriteria eksklusi antara lain ada infeksi, sedang menjalani kemoterapi atau radiasi, pasien dengan keganasan, penyakit hepar kronik, mengalami perdarahan hebat, kondisi lain yang meningkatkan enzim jantung seperti: takiaritmia, gagal jantung dekompensasi bukan karena SKA, hipertensi emergensi, penyakit kritis (sepsis, syok non kardiogenik, luka bakar), emboli paru, myocarditis, gangguan ginjal akut, kejadian neurologi akut (stroke, perdarahan subaraknoid), riwayat infark miokard sebelumnya, pasien sedang mengkonsumsi obat kortikosteroid, terapi trombolitik, inhibitor gp Ilb/Illa, serum lisis, serum ikterik.

Pemeriksaan parameter leukosit dan MPV menggunakan hematology analyzer Sysmex XN-1000, rasio leukosit dan MPV dihitung, skor GRACE didapatkan dari data rekam medis pasien pada saat pertama diperiksa di Instalasi Gawat Darurat RSUP Dr. Kariadi Semarang. Skor GRACE adalah sistem penilaian risiko untuk mengestimasi mortalitas dalam selama perawatan di rumah sakit (30 hari), 6 bulan, dan 3 tahun setelah sindrom koroner akut.

Data dianalisis secara komputerisasi. Seluruh data hasil penelitian ditampilkan dalam bentuk karakteristik umum (deskriptif). Uji normalitas data menggunakan Kolmogorov Smirnov, didapatkan distribusi data normal. Uji hubungan menggunakan uji hubungan Pearson. Analisis statistik diolah menggunakan program komputer, nilai $p$ bermakna bila $<0,05$ dengan interval kepercayaan $95 \%$, nilai korelasi $r=0$ tidak ada korelasi, $r \leq 0,25$ korelasi lemah, $r=0,26-0,50$ korelasi sedang, $r=0,51-0,75$ korelasi kuat, $r=0,76-0,99$ korelasi sangat kuat, $r=1$ korelasi sempurna.

\section{HASIL}

Berdasarkan data pasien SKA di Instalasi Gawat Darurat (IGD) RSUP Dr. Kariadi Semarang selama periode Maret-April 2019, didapatkan 51 subyek penelitian yang memenuhi kriteria inklusi dan eksklusi. Sejumlah 27 (73\%) subyek adalah laki-laki, dengan perempuan 14 subyek (27\%). Tekanan darah diukur dengan menggunakan alat sphygmomanometer air raksa didapatkan rerata tekanan darah sistolik $119 \pm$ $25 \mathrm{mmHg}$, dan rerata tekanan darah diastolik $72 \pm 15$ $\mathrm{mmHg}$. Nadi diukur secara manual dengan menghitung denyut nadi dalam 1 menit, didapatkan rerata $83 \pm 18$ kali per menit. Karakteristik subyek penelitian ditampilkan pada Tabel 1.

Jumlah leukosit didapatkan dari pemeriksaan dengan alat hematology analyzer Sysmex XN-1000 dengan prinsip flowcytometry didapatkan rerata $12.204 \pm 4.000 \mathrm{sel} / \mathrm{uL}$ dan rerata MPV 10,1 $\pm 1,1 \mathrm{fL}$. Rasio leukosit MPV didapatkan dengan membagi jumlah leukosit dengan MPV. Rerata rasio leukosit MPV didapatkan $1215 \pm 382$ (lebih rendah dari cut off penelitian Cicek et al yaitu $1653^{10}$, namun lebih tinggi dari penelitian Dehghani et al yaitu $755 .{ }^{8}$

Skor GRACE didapat dengan melihat catatan rekam medis pasien (penilaian skor GRACE dilakukan saat pemeriksaan awal di IGD) dengan menilai komponen usia (skor 0-91), laju denyut jantung (skor 0-46), tekanan darah sistolik (skor 0-63), kreatinin (skor 2-31), gagal jantung berdasarkan klasifikasi Killip (skor 0-64), adanya henti jantung saat tiba di rumah sakit (skor 43), adanya peningkatan marka jantung (skor 15), dan adanya deviasi segmen ST (skor 30). Rerata skor GRACE $154 \pm 36$, dengan 66,6\% pasien berisiko tinggi mengalami kematian. Uji normalitas dilakukan menggunakan Kolmogorov Smirnov didapatkan variabel rasio leukosit MPV dan skor GRACE berdistribusi normal.

Uji korelasi Pearson dilakukan untuk melihat hubungan antara rasio Leukosit MPV dengan skor GRACE. Didapatkan uji hubungan negatif dengan 
kekuatan lemah antara rasio leukosit MPV dan skor

GRACE saat masuk rumah sakit dengan $r-0,088$.

Tidak didapatkan hubungan bermakna antara rasio leukosit MPV dengan skor GRACE dimana $p=0,538$ $(p>0,05)$. Analisis subgrup pada kelompok pasien dengan risiko

Tabel 1. Karakteristik subyek penelitian

\begin{tabular}{|c|c|c|}
\hline Karakteristik & Rerata \pm SD & Rentang (min - maks) \\
\hline Usia (tahun) & $59 \pm 10$ & $(33-82)$ \\
\hline \multicolumn{3}{|l|}{ Jenis Kelamin } \\
\hline \multicolumn{3}{|l|}{ Laki-laki 27 (73\%) } \\
\hline \multicolumn{3}{|l|}{ Perempuan 14 (27\%) } \\
\hline \multicolumn{3}{|l|}{ Diagnosis } \\
\hline \multicolumn{3}{|l|}{ UAP 5 (9,8\%) } \\
\hline \multicolumn{3}{|l|}{ NSTEMI 13 (25,5\%) } \\
\hline \multicolumn{3}{|l|}{ STEMI $33(64,7 \%)$} \\
\hline Tekanan Darah Sistolik (mmHg) & $119 \pm 25$ & $(46-175)$ \\
\hline Tekanan Darah Diastolik (mmHg) & $72 \pm 15$ & $(20-100)$ \\
\hline Nadi (kali/menit) & $83 \pm 18$ & $(56-152)$ \\
\hline Kreatinin (mg/dL) & $1,3 \pm 0,8$ & $(0,5-6,1)$ \\
\hline Troponin I ( $\mu \mathrm{g} / \mathrm{L})$ & $19,73 \pm 2,85$ & $(0,006-50,00)$ \\
\hline CKMB (U/L) & $114 \pm 124$ & $(12-608)$ \\
\hline Jumlah Leukosit $(/ \mu \mathrm{L})$ & $12.204 \pm 4.000$ & $(5.620-22.200)$ \\
\hline MPV (fL) & $10,1 \pm 1,1$ & $(8,3-13,9)$ \\
\hline Rasio Leukosit MPV & $1215 \pm 382$ & $(504-2155)$ \\
\hline Skor GRACE & $154 \pm 36$ & $(86-255)$ \\
\hline \multicolumn{3}{|l|}{ Risiko kematian rendah (<1\%; Skor GRACE $\leq 108)$ : 3 (5,9\%) } \\
\hline \multicolumn{3}{|l|}{ Risiko kematian menengah (1-3\%, Skor GRACE 109-140): 14 (27,5\%) } \\
\hline Risiko kematian tinggi (>3\%, Skor GRACE >140): $34(66,6 \%)$ & & \\
\hline
\end{tabular}

Tabel 2. Hasil uji korelasi Pearson antara rasio Leukosit MPV dengan Skor GRACE

\begin{tabular}{llc}
\hline & \multicolumn{2}{c}{ Rasio Leukosit MPV } \\
\hline Skor GRACE $(\mathrm{n}=51)$ & $\mathrm{r}=-0,068$ & $\mathrm{p}=0,633$ \\
Analisis subgrup & & $\mathrm{p}=0,129$ \\
Risiko kematian rendah (Skor GRACE $\leq 108)$ & $r=0,980$ & $\mathrm{p}=0,629$ \\
Risiko kematian menengah (1-3\%, Skor GRACE 109-140) & $r=-0,142$ & $\mathrm{p}=0,527$ \\
Risiko kematian tinggi (Skor GRACE >140) & $r=-0,112$ &
\end{tabular}

Keterangan: $p$ bermakna bila $p<0,05 ; r \leq 0,25$ korelasi lemah, $r=0,26-0,50$ korelasi sedang, $r=0,51-0,75$ korelasi kuat, $r=0,76$ 0,99 korelasi sangat kuat

kematian rendah, sedang, tinggi didapatkan nilai $r=0,980(p=0,129) ; r=-0,142(p=0,629) ;$ dan $r=-0,112$ $(p=0,527)$. Analisis subgrup tidak didapatkan hubungan bermakna antara rasio leukosit MPV dengan skor GRACE.

\section{PEMBAHASAN}

Penelitian ini dilakukan untuk mengetahui hubungan rasio leukosit MPV dan skor GRACE untuk menilai prognosis pasien dengan sindrom koroner akut
(SKA). Penilaian prognosis pada pasien dengan SKA penting karena mortalitas pasien SKA tidak hanya saat perawatan di rumah sakit, namun meningkat 6 bulan sampai bertahun-tahun setelah kejadian SKA pertama sehingga pasien dengan prognosis buruk perlu mendapat pemantauan lebih cermat dan terapi yang lebih agresif. ${ }^{15}$ Skor GRACE rutin digunakan pada pasien-pasien SKA yang baru masuk rumah sakit dengan diagnosis SKA namun penilaian ini memerlukan beberapa komponen yang tidak 
didapatkan dalam waktu cepat dan tidak tersedia di semua fasilitas kesehatan seperti kreatinin serum dan penanda kerusakan jantung, sementara pemeriksaan hematologi mudah dan cepat mendapatkan hasil jumlah leukosit dan MPV. ${ }^{16}$ Peningkatan jumlah leukosit merupakan indikator gangguan reperfusi mikrovaskular. Sitokin proinflamasi menstimulasi produksi neutrofil dan monosit di sumsum tulang. Katekolamin endogen dan glukokortikoid yang diinduksi stres dapat memobilisasi leukosit segera setelah onset nyeri dada. ${ }^{2-4}$ Ketika terjadi ruptur plak aterosklerosis, trombosit akan menempel pada sel endotel yang cedera, kemudian teraktivasi. Trombosit teraktivasi melepaskan mediator inflamasim molekul selektin, sitokin dan kemokin. Molekul dan mediator adhesi mengaktivasi leukosit dan mempermudah terjadinya aterotrombosis. ${ }^{8}$ Sementara MPV mengukur ukuran trombosit, dimana trombosit besar diketahui lebih aktif dan memiliki potensi thrombosis lebih besar pada pembuluh darah. ${ }^{15}$ Rasio Leukosit MPV merupakan salah satu parameter hitung darah lengkap yang belum banyak diteliti. Penelitian Adam et al (2018) menunjukkan rasio leukosit MPV menjadi prediktor prognosis kematian dalam 30 hari dan kejadian kardiovaskular mayor paska SKA yang paling baik dibandingkan parameter hematologi lainnya. ${ }^{15}$

Hasil penelitian memperlihatkan rasio leukosit MPV tidak berhubungan signifikan dengan skor GRACE (pada onset 4-6 jam). Hal ini bertentangan dengan beberapa penelitian yang memperlihatkan hubungan signikan antara rasio leukosit MPV dengan kejadian kardiovaskular mayor serta risiko kematian jangka pendek dan jangka panjang. ${ }^{8,10,11,15}$ Belum ada penelitian mengenai hubungan atau perbedaan rasio leukosit MPV dengan skor GRACE.

Penelitian Dehghani et al tahun 2015 menunjukkan peningkatan rasio leukosit MPV secara independen dapat memprediksi insiden Kejadian Kardiovaskular Mayor jangka panjang pada pasien NSTEMI. ${ }^{8}$ Penelitian Cicek et al (2016) menunjukkan semakin tinggi rasio leukosit MPV saat masuk rumah sakit berhubungan dengan keluaran yang lebih buruk pada pasien STEMI, dan rasio leukosit MPV dapat memprediksi mortalitas jangka panjang lebih baik daripada parameter hematologi lain seperti MPV,
RDW, PLR, NLR, dan Kombinasi Leukosit-MPV. ${ }^{10}$ Penelitian pada pasien NSTEMI dengan sindrom metabolik, peningkatan rasio leukosit MPV saat masuk rumah sakit berhubungan dengan peningkatan kejadian kardiovaskular mayor (KKvM). ${ }^{11}$

Ada beberapa faktor yang diprediksi mempengaruhi penelitian ini, diantaranya komponen penilaian skor GRACE yaitu usia dan pengaruh onset dengan saat dilakukannya pemeriksaan. Pengaruh akses medis sebelum pasien ke RSUP Dr. Kariadi juga belum dapat disingkirkan mempengaruhi penilaian jumlah leukosit dan MPV.

Usia diketahui berpengaruh terhadap respon inflamasi secara umum dan pada SKA secara khusus. Penurunan fungsi imunitas bawaan dan adaptif terjadi pada usia lanjut dimulai sejak dekade ke-6, salah satunya terjadi penurunan jumlah leukosit dengan bertambahnya usia. ${ }^{17-20} \mathrm{Hal}$ ini secara tidak langsung mempengaruhi respon peningkatan jumlah leukosit karena inflamasi pada pasien SKA usia lanjut. Selain itu proses penuaan berpengaruh negatif terhadap fungsi sel punca dan sel progenitor hematopoietik yang mempengaruhi kemampuan produksi sel darah. 21,22 Pada penilaian skor GRACE, usia dibagi menjadi 6 kelompok dengan usia $<40$ skor 0 dan usia $>80$ skor 91 (semakin tua usia, risiko mortalitas semakin besar).

Penurunan fungsi imun terjadi seiring bertambahnya usia, maka ada predisposisi inflamasi kronis pada jaringan yang salah satunya menjadi predisposisi aterosklerosis dan meningkatkan insidens SKA. ${ }^{19,23}$ Semakin bertambahnya usia, terjadi peningkatan kadar interleukin 6 , interleukin $1 \beta$, dan tumor necrosis factor a yang berkontribusi atas stimulasi sistem imun terus menerus, sehingga terjadi inflamasi sublinis. ${ }^{22}$ Keadaan inflamasi kronis ini juga mempengaruhi MPV baseline pasien. Semakin lanjut usia terutama setelah dekade ke-6, maka MPV cenderung lebih tinggi linear dengan usia. ${ }^{24}$ Hubungan MPV sendiri dalam memprediksi kejadian kardiovaskular mayor pada pasien SKA masih kontroversi, beberapa penelitian menunjukkan tidak ada hubungan peningkatan MPV saat masuk rumah sakit dengan kejadian kardiovaskular mayor, sementara penelitian lain menunjukkan MPV merupakan prediktor independen kematian dalam 30 
hari pada pasien STEMI paska Percutaneous Coronary Intervention (PCl). ${ }^{2,15}$

Trombosit berperan dalam proses trombosis pada SKA, yang akan mengkonsumsi trombosit berukuran besar (reaktif). Proses ini terjadi permanen pada infark miokard, berlawanan dengan agregasi dan konsumi trombosit yang berulang pada UAP. Maka pada beberapa penelitian didapatkan MPV pada infark miokard lebih rendah daripada UAP. Pada penelitian lain didapatkan MPV yang sama antara UAP dan infark miokard dikarenakan adanya kondisi inflamasi sehingga MPV baseline cenderung tinggi. ${ }^{2}$ Nilai MPV $(\geq 11.01 \mathrm{fL}$ ) berisiko kematian lebih tinggi pada pasien SKA. ${ }^{25}$ Usia kemungkinan mempengaruhi rasio leukosit MPV terutama pada usia lanjut dimana respon leukosit terhadap inflamasi cenderung lebih rendah sementara MPV cenderung lebih tinggi (rasio menjadi kecil), sedangkan pada penilaian skor GRACE usia lebih lanjut memberikan skor semakin besar.

Skor GRACE merupakan hasil penelitian model regresi logistik multivariabel skala besar dan multinasional sehingga didapatkan delapan faktor risiko independen yang dapat memprediksi mortalitas pasien SKA. ${ }^{12,26}$ Tidak semua variabel berkaitan dengan inflamasi, sedangkan penilaian rasio leukosit MPV untuk menilai kondisi inflamasi. Kemungkinan adanya variabel dari skor GRACE yang tidak berkaitan dengan inflamasi mempengaruhi hasil penelitian ini.

Penelitian Nunez et al menunjukkan penilaian leukosit dalam memprediksi mortalitas jangka panjang adalah penilaian dalam beberapa jam pertama setelah onset SKA. ${ }^{7}$ Penilaian leukosit dalam penelitian ini dilakukan 4-6 jam setelah onset SKA, penilaian pada waktu yang lebih cepat ( $<4$ jam) atau lebih lambat $(>6$ jam) mungkin dapat memberikan gambaran berbeda.

Beberapa pasien penelitian sudah mencari pertolongan pertama ke RS lain atau klinik mungkin telah diberikan pertolongan pertama berupa obat antitrombosit, seperti aspirin dan clopidogrel. Aspirin telah terbukti tidak mempengaruhi ukuran trombosit. Namun clopidogrel secara in vitro terbuti menghambat peningkatan MPV. ${ }^{25,27}$ Penelitian ini hanya menggunakan data awal saat pasien pertama kali ditangani di IGD dan tidak menggunakan data-data sebelum pasien sampai di IGD.

\section{SIMPULAN}

Tidak terdapat hubungan antara rasio leukosit MPV dengan skor GRACE.

\section{SARAN}

Perlu dilakukan penelitian lebih lanjut terkait dengan outcome pasien dan dengan memperhatikan faktor usia, onset penyakit (lebih dari 6 jam), dan terapi yang diterima sebelum pasien dirujuk.

\section{UCAPAN TERIMA KASIH}

Terima kasih kepada semua pihak yang telah membantu dalam pelaksanaan penelitian. Terima kasih kepada Direktur Umum RSUP Dr. Kariadi Semarang yang telah memberikan izin melaksanakan penelitian, dosen bagian patologi klinis FK Undip Semarang atas bimbingan mulai dari perencanaan sampai publikasi, serta staf bagian laboratorium dan rekam medis atas bantuannya dalam pelaksanaan penelitian ini.

\section{DAFTAR PUSTAKA}

1. Badan Penelitian dan Pengembangan Kesehatan Kementerian Kesehatan Republik Indonesia. Riset Kesehatan Dasar 2013. Jakarta: Kementerian Kesehatan Republik Indonesia; 2013.hIm.268.

2. Odeberg J, Freitag M, Forssell H, Vaara I, Persson $\mathrm{ML}$, Odeberg $\mathrm{H}$, et al. Influence of pre-existing inflammation on the outcome of acute coronary syndrome: A cross-sectional study. BMJ Open. 2016;6(1):1-8

3. Libby P. Coronary syndromes. Am Hear Assoc. 2001;114(12):365-72.

4. Göktaş MU, Akyol PY, Karakaya Z, Payza U, Topal FE. Evaluation of white blood cell and neutrophil/lymphocyte ratio in acute coronary syndrome patients admitted to emergency department. Biomed Res. 2018;29(10):2009-14.

5. Grzybowski M, Welch RD, Parsons L, Ndumele $\mathrm{CE}$, Chen E, Zalenski R, et al. The association between white blood cell count and acute myocardial infarction in-hospital mortality: findings from the national registry of myocardial infarction. Acad Emerg Med. 2004;11(10):1049-60. 
6. Byrne CE, Fitzgerald A, Cannon CP, Fitzgerald DJ, Shields DC. Elevated white cell count in acute coronary syndromes: Relationship to variants in inflammatory and thrombotic genes. BMC Med Genet. 2004;5:1-11.

7. Núñez J, Fácila L, Llàcer A, Sanchís J, Bodí V, Bertomeu $\mathrm{V}$, et al. Prognostic value of white blood cell count in acute myocardial infarction: long-term mortality. Rev Esp Cardiol. 2005;58(6):631-9.

8. Dehghani MR, Rezaei Y, Taghipour-Sani L. White blood cell count to Mean Platelet Volume ratio as a novel non-invasive marker predicting long-term outcomes in patients with non-ST elevation acute coronary syndrome. Cardiol J. 2015;22(4):437-45.

9. Niu X, Liu G, Huo L, Zhang J, Bai M, Peng Y, et al. Risk stratification based on components of the complete blood count in patients with acute coronary syndrome: A classification and regression tree analysis. Sci Rep. 2018;8(1):1-12.

10. Çiçek G, Açıkgöz SK, Yayla, Kundi H, İleri M. White blood cell count to Mean Platelet Volume ratio: A novel and promising prognostic marker for st-segment elevation myocardial infarction. Cardiol J. 2016;23(3):225-35.

11. Dehghani MR, Rezaei $\mathrm{Y}$, Fakour S, Arjmand N. White blood cell count to Mean Platelet Volume ratio is a prognostic factor in patients with Non-ST elevation acute coronary syndrome with or without metabolic syndrome. Korean Circ J. 2016; 46 (2): 229-38.

12. Muthappan P, Rogers A, Eagle K. Using the GRACE Risk Scores in Everyday Practice. AJM. 2012;125(2):144-7.

13. Cakar MA, Sahinkus S, Aydin E. Relation between the GRACE score and severity of atherosclerosis in acute coronary syndrome. J Cardiol. 2014; 63 (1):24-8.

14. Tadashi J, Liu N, Xiong Z, Xue N, Fung J, Liam M, et al. Comparing HEART, TIMI, and GRACE scores for prediction of 30-day major adverse cardiac events in high acuity chest pain patients in the emergency department. Int J Cardiol. 2016; 221:759-64.

15. Adam AM, Rizvi AH, Haq A, Naseem R, Rehan A, Shaikh AT, et al. Prognostic value of blood count parameters in patients with acute coronary syndrome. Indian Heart J. 2018;70(2):233-40.

16. Abbase AH, Khadim MAK. Leukocytes count and neutrophil/ lymphocytes ratio in predicting inhospital outcome after acute myocardial infarction. Medical Journal of Babylon. 2010;7(4-3):480-9.

17. Badran HM, Elnoamany MF, Khalil TS, Eldin MME. Age-related alteration of risk profile, inflammatory response, and angiographic findings in patients with acute coronary syndrome. Clin Med Cardiol. 2009;3:CMC.S2118.

18. Fuentes E, Fuentes M, Alarcón M, Palomo I. Immune system dysfunction in the elderly. An Acad Bras Cienc. 2017;89(1):285-99.

19. Weyand CM, Goronzy JJ. Aging of the immune system: Mechanisms and therapeutic targets. Ann Am Thorac Soc. 2016;13(5):S422-8.

20. Valiathan R, Ashman M, Asthana D. Effects of aging on the immune system: infants to elderly. Scand J Immunol. 2016;83(4):255-66.

21. Dorshkind K, Swain S. Age-associated declines in immune system development and function. Current Opinion in Immunology. 2009;21(4):404-7.

22. Weiskopf D, Weinberger B, Grubeck-Loebenstein B. The aging of the immune system. Transpl Int. 2009;22(11):1041-50.

23. Kale SS, Yende S. Effects of aging on inflammation and hemostasis through the continuum of critical illness. Aging Dis. 2011; 2 (6): 501-11.

24. Verdoia M, Schaffer A, Barbieri L, Bellomo G, Marino $P$, Sinigaglia $F$, et al. Impact of age on Mean Platelet Volume and its relationship with coronary artery disease: A single-centre cohort study. Exp Gerontol. 2015;62:32-6.

25. Slavka G, Perkmann T, Haslacher H, Greisenegger S, Marsik C, Wagner OF, et al. Mean platelet volume may represent a predictive parameter for overall vascular mortality and ischemic heart disease. Arterioscler Thromb Vasc Biol. 2011; 31 (5):1215-8.

26. Goodman SG, Flather MD, Fox KAA. Predictors of hospital mortality in the global registry of acute coronary events. Arch Intern Med. 2015;163:234553. 
27. Shah B, Valdes V, Nardi MA, Hu L, Schrem E, Berger JS. Mean platelet volume reproducibility and association with platelet activity and anti-platelet therapy. Platelets. 2014;25(3):188-92. 